\title{
PENGEMBANGAN PERANGKAT PEMBELAJARAN FSIKA BERBASIS SETS UNTUK MENINGKATKAN KEMAMPUAN BERPIKIR KREATIF SISWA
}

\author{
Andista Candra Yusro \\ Program Studi Pendidikan Fisika, Fakultas PMIPA \\ IKIP PGRI MADIUN \\ andista@ikippgrimadiun.ac.id
}

\begin{abstract}
Abstrak
Pengembangan kreatifitas peserta didik merupakan bagian yang tidak terpisahakan dalam upaya peningkatan sumber daya manusia Indonesia. Peningkatan sumber daya tersebut menuntut komitmen dalam memupuk dan mengembangkan kreatifitas yang secara mendasar dimiliki oleh seluruh umat manusia. Penelitian ini bertujuan untuk menghasilkan perangkat pembelajaran fisika dengan model SETS untuk meningkatkan kemampuan berpikir kreatif yang valid, praktis dan efektif. Penelitian yang dilakukan meruapakan penelitian pengembangan yang mengadopsi model pengembangan plomp. Berdasarkan hasil uji validitas kepada dosen ahli dan ahli diapatkan skor rata-rata penilaian perangkat pembelajaran adalah 4,27 yang dikategorikan sangat baik. Berdasarkan hasil uji statistik terhadap nilai pretest dan postest siswa didapatkan bahwa nilai signifikansi 0,034. Hasil signifikansi tersebut $0,034<$ 0,05 sehingga dapat ditarik sebuah kesimpulan bahwa penerimaan terhadap Ha, sehingga disimpulkan terdapat perbedaan kemampuan berpikir kreatif siswa antara sebelum dan sesudah pelaksanaan pembelajaran.
\end{abstract}

Kata Kunci : Perangkat Pembelajaran, SETS, Berpikir Kreatif

\section{PENDAHULUAN}

Pendidikan nasional juga bertujuan mengembangkan kemampuan, salah satu kemampuan yang dikembangkan yaitu kemampuan berpikir kreatif. Berfikir kreatif tergolong kompetensi tingkat tinggi (high order competencies) dan dapat dipandang sebagai kelanjutan dari kompetensi dasar (basic skills). Hal tersebut sejalan dengan pernyataan Ervync (1991) bahwa kreatifitas memainkan peran yang penting dalam siklus berfikir matematis tingkat lanjut. Selanjutnya menurut Career Center Maine Departmen of Labor USA, kemampuan berpikir kreatif memang penting karena kemampuan ini merupakan salah satu kemampuan yang dikehendaki dunia kerja (Mahmudi, 2010). Pernyataan-pernyataan tersebut mengindikasikan bahwa kemampuan berpikir kreatif adalah kemampuan yang penting untuk ditingkatkan.

Belajar kreatif tidaklah secara kebetulan akan tetapi membutuhkan proses yang mendukung tercapainya kemampuan tersebut. Untuk merangsang belajar kreatif, diperlukan persiapan antara lain dengan menyiapkan suatu lingkungan kelas yang merangsang anak-anak untuk belajar kreatif. Anwar et al (2012), berfikir kreatif adalah cara baru dalam melihat dan mengerjakan sesuatu yang memuat 4 aspek antara lain, fluency (kefasihan), flexybility (keluwesan), originality (keaslian), dan elaboration (keterincian). Dari berbagai definisi dapat disimpulkan bentuk perilaku dari berpikir kreatif sebagi berikut.

Tabel 1 Prilaku Kemampuan Berpikir Kreatif

\begin{tabular}{ll}
\hline \multicolumn{1}{c}{ Indikator KBK } & Perilaku KBK \\
\hline Kelancaran (fluency) & $\bullet$ kemampuan menghasilkan banyak gagasan/jawaban \\
\hline Kerincian (elaboration) & $\begin{array}{l}\text { - kemampuan memiliki gagasan baru } \\
\text { - kemampuan merinci detail-detail tertentu }\end{array}$ \\
\hline Fleksibilitas (felxibility) & $\begin{array}{l}\text { - mampu menghasilkan gagasan, jawaban atau pertanyaan dari sudut } \\
\text { padang yang berbeda }\end{array}$ \\
\hline
\end{tabular}


JPFK, Vol. 1 No. 2, September 2015, hal 61 - 66

http://e-journal.ikippgrimadiun.ac.id/index.php/JPFK

- Kemampuan memberikan arah pemikiran yang berbeda

Orisinalitas (originality)

- Banyaknya variasi kemampuan memberikan jawaban yang tidak lazim, lain dari yang lain dan jarang diberikan

- banyak variasi kemampuan memberikan arah pemikiran yang berbeda

Pendekatan SETS dalam pembelajaran Fisika dapat diterapkan pada semua konsep-konsep Fisika kecuali ada keterbatasan pada konsep Fisika teori yang memerlukan kecepatan mendekati kecepatan cahaya untuk mempraktekkannya pada teknologi, misalnya pada konsep relativitas.

Menurut Munandar (2002), berdasarkan pertimbangan bahwa perilaku kreatif tidak hanya memerlukan kemampuan berpikir kreatif (kognitif), tetapi juga sikap kreatif (afektif). Pendekatan SETS mencakup topik dan konsep yang berhubungan dengan sains, lingkungan, teknologi dan hal-hal yang berkenaan dengan masyarakat. SETS membahas tentang hal-hal bersifat nyata, yang dapat dipahami, dapat dibahas dan dapat dilihat. Membicarakan unsur-unsur SETS secara terpisah yaitu sains, lingkungan, teknologi, dan masyarakat, berarti unsur ini selanjutnya dicoba untuk menghubungkan keberadaan konsep sains dalam semua unsur SETS agar bisa didapatkan gambaran umum dari peran konsep tersebut dalam unsur-unsur SETS yang lainnya oleh Binadja (2006a).

Karakteristik pendekatan SETS dalam proses pembelajaran Fisika dapat disebutkan beberapa diantaranya sebagai berikut : (1) bertujuan memberi pembelajaran Fisika secara kontekstual, (2) siswa dibawa ke situasi untuk memanfaatkan konsep Fisika ke bentuk teknologi untuk kepentingan masyarakat, (3) siswa diminta berpikir tentang berbagai kemungkinan akibat yang terjadi dalam proses pentransferan konsep Fisika ke bentuk teknologi, (4) siswa diminta untuk menjelaskan keterhubungkaitan antara unsur konsep Fisika yang diperbincangkan dengan unsurunsur lain dalam SETS yang mempengaruhi berbagai keterkaitan antar unsur tersebut., (5) siswa dibawa untuk mempertimbangkan manfaat atau kerugian dari penggunaan konsep Fisika bila diubah dalam bentuk teknologi yang relevan, (6) siswa diajak membahas tentang SETS dari berbagai arah dan dari berbagai titik awal tergantung pengetahuan dasar yang dimiliki siswa bersangkutan.

Materi listrik dinamis yang dipelajari SMA merupakan pemantapan dari materi yang telah merka pelajari sebelumnya pada jenjang SMP. Materi meliputi hukum ohm, rangkaian listrik, rangkaian komponen listrik dan hukum kirchoff. Penentuan materi ini didasarkan kepada hasil dari investigasi awal yang selanjutnya disepakati bersama dengan guru bidang studi.

\section{METODE PENELITIAN}

Penelitian ini menggunakan model pengembangan Plomp yang dikembangkan oleh Tjeerd Plomp (1997). Penelitian ini dilakukan dalam beberapa tahap. Tahap investigasi awal, perancangan, dan realisasi/konstruksi dilakukan pada bulan Maret 2015. Tahap tes, evaluasi dan revisi dilakukan pada bulan April-Mei 2015 di MAN 1 Madiun. ini adalah:

Tahapan yang dilakukan dalam penelitian

1. Tahap Investigasi Awal. Pengumpulan data yang dilakukan pada tahap ini berupa data deskriptif yang dibutuhkan dalam pengembangan perangkat pembelajaran fisika berbasis SETS pada materi Listrik Dinamis. Pada tahap ini dilakukan analisis kebutuhan dan analisis silabus fisika SMA pada materi listrik dinamis.

2. Tahap Perancangan. Pada tahap ini dirancang bentuk perangkat yang ingin dikembangkan disertai dengan rencana suplemen yang digunakan dalam melaksanakan kegiatan KBM dikelas. Pada Tahapan ini di putuskan rancangan perangkat pembelajaran meliputi RPP, Bahan Ajar, Instrumen Evaluasi. Penekanan pada tahapan ini ada pada 3 aspek diantaranya aspek : format, isi dan bahasa.

3. Tahap Realisasi. Pada tahap ini menghasilkan perangkat pembelajaran fisika berbasis SETS pada materi listrik dinamis serta instrumen penelitian sebagai lanjutan dari tahap perancangan. Perangkat pembelajaran fisika berbasis SETS pada materi listrik dinamis yang dihasilkan pada tahap ini selanjutnya disebut Draf I.

4. Tahap Tes, Evaluasi dan Revisi. Pada tahap ini dilakukan proses validasi ahli dan uji cobaterbatas. Proses validasi ahli merupakan proses evaluasi yang dilakukan dengan 
mengkonsultasikan draf I kepada validatoryaitu dosen pendidikan fisika untukdilakukan uji validitas perangkat pembelajaran fisika berbasis SETS pada materi listrik dinamis. Validitas yang dilakukan adalah validitas format, isi, dan bahasa. Validitas format bertujuan untuk mendapatkan gambaran tentang kesesuaian komponen yang terdapat pada perangkat pembelajaran. Validitas isi bertujuan untuk mengetahui kesesuaian materi yang digunakan. Validitas bahasa bertujuan untuk mengetahui ketepatan bahasa yang digunakan dalam perangkat pembelajaran. Berdasarkan hasil konsultasi dan saran dari validator akan digunakan untuk perbaikan perangkat pembelajaran fisika berbasis SETS pada materi listrik dinamis, selanjutnya atas keputusan/kesimpulan validator digunakan untuk melanjutkan penelitian ke tahap uji coba dengan revisi atau tidak dengan revisi sehingga menghasilkan draf II. Selanjutnya Draf II yang telah dihasilkan akan diuji coba terbatas untuk melihat kepraktisan perangkat pembelajaran yang dikembangkan. Uji coba ini dilakukan pada sampel siswa yang bersifat heterogen dengan jumlah sampel 20 siswa. Sampel siswa ini untuk selanjutnya yang akan dikenai sebagai subjek penelitian, setelah treatment diberikan siswa diminta untuk mengomentari dan mengisi angket terhadap pelaksanaan pembelajaran sesuai dengan perangkat pembelajaran yang telah dikembangkan. Hasil angket akan dianalisis kemudian berdasarkan komentar langsung mahasiswa dan temuan dilapangan perangkat pembelajaran akan direvisi akan direvisi.

\section{HASIL DAN PEMBAHASAN}

Hasil penelitian Pengembangan Perangkat Pembelajaran Fisika Pada Listrik Dinamis untuk Meningkatkan Kemampuan Berpikir Kreatif Siswa ini menggunakan model Plomp. Model Plomp terdiri dari tahap investigasi awal, perancangan, realisasi, tes, evaluasi dan revisi, dan implementasi. Namun, pada penelitian ini tidak sampai pada tahap implementasi.

\section{Tahap Investigasi Awal}

Hasil temuan yang ditemukan pada tahapan ini adalah 1) Peserta didik mengalami kesulitan dalam menghadapi konsep, hitungan matematis dan penerapan ilmu pengetahuan yang dipelajari dikelas dengan kehidupan nyata mereka; 2) Orientasi pembelajaran masih pada textbook pemanfaatan alam sekitar sebagai bagian pembelajaran belum dioptimalkan; 3) Pembelajaran dengan SETS belum pernah disampaikan dalam mengajarkan materi listrik dinamis disekolah tersebut.

Bersama dengan guru sekolah kemudian disepakati dan dirumuskan indiaktor pembelajaran yang terlebih dahulu diawali dengan analisis silabus dipilihlah standar kompetensi 5. Menerapkan konsep kelistrikan dalam berbagai penyelesaian masalah dan berbagai produk teknologi dan KD 5.1 Memformulasikan besaranbesaran listrik rangkaian sederhana (satu loop) tertutup.

\section{Tahapan Perancangan}

Tahap perancangan ini yang dilakukan adalah mendesain perangkat pembelajaran yang meliputi : menentukan perumusan tujuan pembelajaran, merancang perangkat pembelajaran beserta menentukan kelengkapan pendukung perangkat pembelajaran, menyuisun indikartor instrumen evaluasi pembelajaran dan menysusn instrumen penelitian.

\section{Tahap Realisasi}

Berdasarkan perumusan draf pada tahapan perancangan selanjutnya disusunlah perangkat pembelajaran berbasis SETS pada materi listrik dinamis yang harapannya dengan pembelajaran tersebut dapat meningkatkan pemahaman dan kemampuan berpikir kreatif dari siswa. Perangkat pembelajaran yang berhasil dikembangkan pada tahap ini meliputi RPP, bahan ajar dan Instrumen evaluasi pembelajaran. Perangkat pembelajaran yang dihasilkan pada tahap ini selanjutnya disebut draf I.

\section{Tahap Tes, Evaluasi dan Revisi}

Tahapan ini dilakukan validasi terhadap perangkat pembelajaran yang dikembangkan kepada validator untuk mengetahui tingkat validitas produk dan uji coba terbatas kepada siswa sampel penelitian untuk mengetahui tingkat kepraktisan dari produk yang dikembangkan.

\section{Validasi Ahli}

Hasil validasi yang dilakukan oleh 5 orang validator yang terdiri dari 3 orang dosen dan dua 


\section{JPFK, Vol. 1 No. 2, September 2015, hal 61 - 66 \\ http://e-journal.ikippgrimadiun.ac.id/index.php/JPFK}

orang guru pada aspek format, isi dan bahasa

secara kesulurah terangkum pada tabel 2.

Tabel 2. Hasil Validasi draf produk I oleh dosen ahli dan guru

\begin{tabular}{ccc}
\hline $\begin{array}{c}\text { Validator } \\
\text { Produk }\end{array}$ & Rerata & Kategori \\
\hline Silabus & 4,2 & Sangat baik \\
\hline RPP & 4,31 & Sangat baik \\
\hline Bahan Ajar & 4,2 & Sangat baik \\
\hline Intrumen Evaluasi & 4 & Sangat baik \\
\hline
\end{tabular}

Selain melakukan penilaian terhadap produk

Hasil validasi terhadap perangkat pembelajaran yang dikembangkan meliputi aspek silabus, RPP, yang dikembangkan validator juga memberikan beberapa saran terkait dengan produk yang Bahan Ajar dan Instrumen Evaluasi dengan skor dikembangkan yang terangkum dalam tabel 3. rata-rata 4,27 dengan karegori sangat baik.

Tabel 3.Hasil Revisi dan validasi perangkat pembelajaran

\begin{tabular}{llll}
\hline Jenis Perangkat & Sebelum Revisi & Sesudah Revisi \\
\hline Silabus & $\begin{array}{l}\text { Nomor standar kompetensi ada yang } \\
\text { tidak urut }\end{array}$ & $\begin{array}{l}\text { Nomor Standar kompetensi } \\
\text { diurutkan }\end{array}$ \\
\hline RPP & $\begin{array}{l}\text { Indikator dan tujuan pembelajaran } \\
\text { pada RPP belum dilengkapi dengan } \\
\text { kognitif produk, proses dan sikap }\end{array}$ & $\begin{array}{l}\text { Menambahkan pada indikator dan } \\
\text { tujuan pembelajaran kognitif } \\
\text { produk, proses dan sikap }\end{array}$ \\
\hline Bahan Ajar & $\begin{array}{l}\text { Keterkaitan antara materi listrik } \\
\text { dinamis dengan konsep pembelajaran }\end{array}$ & $\begin{array}{l}\text { Revisi materi ajar penekanan pada } \\
\text { keterkaitan SETS dengan materi } \\
\text { listrik dinamis }\end{array}$ \\
\hline Instrument & SETS perlu dipertajam & Porsi soal untuk mengukut \\
Evaluasi & Soal yang kaitannya menumbuhkan \\
kreatifitas siswa ditambah & kreatifitas siswa ditambah \\
\hline
\end{tabular}

selesai kesuluran treatment pembelajaran dengan

\section{Uji Coba Terbatas}

Perangkat pembelajaran yang telah mendapatkan penilaian dari validtor berserta saransaran perbaikan kemudian direvisi. Hasil revisi terhadap produk pengembangan perangkat pembelajaran selanjutnya menjadi produk draf II. Sampel penelitian 20 orang siswa yang diambil dari polulasi yang bersifat heterogen kemudian mendapatkan treatment dengan menggunakan perangkat pembelajaran yang telah dikembangkan.

Pada tahapan ini siswa melakan seluruh proses pembelajaran dengan didampaikan reviewer untuk memastikan jalannya kegiatan pembelajaran sesuai dengan rencana pada perangkat menggunakan perangkat yang dikembangkan siswa diminta untuk mengisi angket terkait dengan ke praktisan pembelajaran yang telah mereka lakukan. Dari 20 orang siswa hasil angket dengan skor 3,4 dengan kategori praktis, temuan ini mengindikasikan siswa senang belajar dengan model dan serangkaian pembelajaran sesuai dengan perangkat yang telah dikembangkan. Respon yang ditunjjukan peserta didik terhadap pembelajaran fisika berbasis SETS yang dikembangkan rata-rata baik.

Hasil belajar siswa yang mencerminkan kreatifitas siswa selanjutnya didapatkan dari hasil nilai pretest dan posttest. Deskripsi data hasil pembelajaran yang telah dikembangkan. Setelah

belajar siswa ditampilkan pada tabel 4 .

Tabel 4. Deskripsi kemampuan berpikir kreatif siswa

\begin{tabular}{cccc}
\hline Jenis Tes & $\mathrm{N}$ & Mean & Stadar Deviasi \\
\hline Pretest & 20 & 52,31 & 8,48 \\
\hline Postest & 20 & 64,58 & 7,51 \\
\hline
\end{tabular}

$0,034<0,05$ sehingga dapat ditarik sebuah

Uji Statistik untuk mengetahui perbedaan hasil prestest dan post test siswa menggunakan SPSS 18. Berdasarkan hasil uji tersebut didapatkan bahwa nilai signifikansi 0,034. Hasil signifikansi tersebut kesimpulan bahwa penerimaan terhadap $\mathrm{Ha}$ atau penolakan Ho. Ho: tidak terdapat perbedaan kemampuan berpikir kreatif siswa dari siswa antara sebelum dan sesudah melakasanakan

\section{$64 \mid$ Yusro, Pengembangan Perangkat Pembelajaran Fsika Berbasis SETS ...}


kegiatan. Ha : Ha: terdapat perbedaan kemampuan berpikir kreatif siswa dari siswa antara sebelum dan sesudah melakasanakan kegiatan.

Hasil evaluasi proses pembelajaran selama pembelajaran fisika dengan perangkat berbasis SETS yang dikembangkan setelah diterapkan dan catatan harian oleh peneliti dan observer, maka diperoleh tanggapan peserta didik dan observer sebagai respon terhadap pembelajaran dengan model SETS selama pelaksanaan pembelajaran, yaitu (a) secara keseluruhan respon positif diebrikan oleh peserta didik telah terhadap pembelajaran yang dilakukan, sikap ini dapat ditafsirkan, bahwa sebagian besar mereka mengetahui dengan jelas sasaran pembelajaran yang ingin dicapai; (b) peserta didik menyatakan pembelajaran dengan model SETS yang diterapkan telah menunjukkan secara jelas domain kreativitas peserta didik yang harus dikembangkan; (c) kondisi pembelajaran menurut peserta didik sudah mengarah bepusat pada pembelajaran fisika dengan model SETS untuk kreativitas peserta didik, penguasaan konsep dan kreativitas peserta didik; (d) peserta didik berpendapat bahwa kegiatan belajar mengajar yang mereka alami merupakan hal baru karena dalam pembelajaran mereka dilengkapi dengan media pembelajaran yang menunjang, bahan ajar dan lembar kerja yang membuat mereka semangat untuk belajar. Purwandari et. all (2015) menyampaikan bahwa pembelajaran fisika dengan menggunakan modul fisika berbasis SETS dapat meningkatkan kemampuan berpikir kritis siswa.

Menindaklanjuti hasil penelitian yang telah dilakukan, maka perlu dilakukan pembahasan satu per satu hasil penelitian yang telah diperoleh. Kreativitas belajar peserta didik dapat diukur dalam aspek kognitif, psikomotorik dan dalam aspek afektif. Aspek kognitif mengacu pada cara berpikir divergen diukur melalui tes kreativitas verbal, sedangkan dari aspek afektif diukur melalui observasi kegiatan pembelajaran yang berlangsung. Hasil pengamatan secara observasi menunjukkan, bahwa selama pembelajaran berlangsung, peserta didik terlihat bersemangat mengikuti. Berdasarkan hasil respon ini dapat diketahui kelemahan dan kelebihan perangkat ini, sehingga ke depannya dapat disempurnakan lagi khususnya dalam hal yang berhubungan dengan kegiatan sehari-hari.

Kesimpulan
Perangakat pembelajaran fisika berbasis SETS untuk meningkatkan kreatifitas siswa yang dikembangkan beerdasarkan peneliaian dari validator (dosen ahli dan guru) disepakati bahwa produk valid, dengan perolehan skor rata-rata hasil validasi 4,27 yang dikategorikan sangat baik. Hasil uji stastistik terhadap nilai pretest dan posttest siswa menunjukkan adanya perbedaan kemampuan berpikir kreatif siswa sebelum dan sesudah perlakuan.

\section{SARAN}

Penelitian pengembangan ini dapat digunakan sebagai rujukan dalam mengembangkan perangkat pembelajaran fisika pada materi yang lain. Pembelajaran dengan model SETS dirasakan dapat diterapkan pada berbagai matei dalam fisika sehingga disarankan untuk mengembangkannya untuk pokok bahasan fisika yang lain.

\section{DAFTAR PUSTAKA}

Anwar, N. M. et al. (2012). A Comparison of Creative Thinking Abilities of High and Low Achievers Secondary School Students. International Interdiciplinary Journal of Education, 1(1)

Binadja, A. (2006a). Pedoman Pengembangan Silabus Bervisi dan Berpendekatan SETS (Science, Environment, Technology, and Society) atau (Sains, Lingkungan, Teknologi dan Masyarakat) Bahan Pembelajaran Penerbitan Khusus Media MIPA UNNES. Semarang: Laboratorium SETS. Universitas Semarang

Ervync, G. (1991). "Mathematical Creativity". Dalam Tall, D. Advanced Mathematical Learning. London: Kluwer Academic Publisher.

Mahmudi, A. (2010). Mengukur Kemampuan Berpikir Kreatif Matematis. Konferensi Nasional Matematika XV. UNIMA Manado

Munandar, S. C. U. (2002). Kreativitas dan Keberbakatan Strategi Mewujudkan Potensi Kreatif dan Bakat. Jakarta: PT Gramedia Pustaka Utama.

Plomp, Tj. 1997. Educational Design: Introduction. From Tjeerd Plomp (eds). 
JPFK, Vol. 1 No. 2, September 2015, hal 61 - 66

http://e-journal.ikippgrimadiun.ac.id/index.php/JPFK

Educational \& Training System Design:

Introduction. Design of Education and

Training (in Dutch).Utrecht (the Netherlands): Lemma. Netherland.Faculty of Educational Science and Technology, University of Twen

Purwandari, P., Huriawati, F., Yusro, A. C., \& Wibowo, R. T. (2015). Pengembangan Modul Pembelajaran Fisika Berorientasi SETS Pada Materi Listrik Dinamis Untuk Meningkatkan Kemampuan Berfikir Kritis Siswa. Jurnal Penelitian LPPM (Lembaga Penelitian dan Pengabdian kepada Masyarakat) IKIP PGRI MADIUN, 2(2). 